\title{
PENGARUH PELATIHAN TERHADAP PRODUKTIVITAS KERJA PEGAWAI PADA DINAS KETAHANAN PANGAN KABUPATEN LAMPUNG BARAT
}

\author{
Tri Purnama Ningsih ${ }^{(1)}$, Trisnowati Josiah ${ }^{(2)}$, Khairul Saleh $^{(3)}$ \\ Fakultas Ekonomi Universitas Sang Bumi Ruwa Jurai \\ ningsih.tp05@gmail.com,trisnowati.josiah@fe.saburai.ac.id,khairul.saleh@fe.saburai.ac.id
}

\begin{abstract}
Abstrak. Proses pembelajaran yang dirancang untuk mengubah kinerja orang dalam melakukan pekerjaannya. Pelatihan merupakan cara yang digunakan oleh setiap perusahaan dalam mengembangkan skill and knowledge bagi para karyawannya. Tingkat keahlian dan spesikasi pegawai pada Dinas Ketahanan Pangan Kabupaten Lampung Barat masih kurang, kualitas kinerja pegawai yang belum optimal, sehingga perlu ada solusi untuk mengatasinya. Tujuan dari untuk mengetahui Pengaruh Pelatihan Terhadap Produktivitas kerja Pegawai Pada Dinas Ketahanan Pangan Kabupaten Lampung Barat. Hipotesis yang diajukan dalam penelitian ini adalah "Pelatihan berpengaruh terhadap Produktivitas kerja Pegawai Pada Dinas Ketahanan Pangan Kabupaten Lampung Barat". Pengumpulan data penelitian menggunakan teknik populasi penelitian dari 24 responden. Metode penelitian yang digunakan adalah analisis kuantitatif yaitu regresi linier sederhana. Berdasarkan hasil analisis diperoleh persamaan bahwa : $\mathrm{Y}=13,859+0,423(\mathrm{X})$. Hasil pengujian menggunakan rumus $t$ student, menunjukkan bahwa $t_{\text {hitung }} 4,640>t_{\text {tabel }} 2,068$, berarti Ho ditolak dan Ha diterima, dengan demikian hipotesis yang diajukan dapat diterima.
\end{abstract}

Kata kunci: Keahlian, Kinerja, Pelatihan, Produktivitas.

\section{PENDAHULUAN}

Keberhasilan dan kegagalan pembangunan tidak lepas dari peran yang dimainkan aparatur pemerintahan sebagai abdi negara dan abdi masyarakat. Peranan tersebut diwujudkan dalam bentuk kepemimpinan dalam organisasi yang menjadi penggerak bawahan dan menjadi satu kesatuan pola manajemen pemerintahan dan manajemen pembangunan di daerah.

Dalam rangka mencapai tujuan tersebut, Dinas Ketahanan Pangan Kabupaten Lampung Barat, berperan secara aktif untuk mengoordinasikan, mensinkronkan dan mendorong seluruh pemangku kepentingan baik secara horizontal maupun vertikal dalam mewujudkan ketahanan pangan sampai tingkat perseorangan dengan berlandaskan kedaulatan pangan dan kemandirian pangan secara berkesinambungan. Perwujudan ketahanan pangan tersebut ditandai dengan tiga hal pokok yang harus diperhatikan, yaitu: (i) ketersediaan pangan yang berbasis pada pemanfaatan sumber daya lokal secara optimal; (ii) keterjangkauan pangan dari aspek fisik dan ekonomi oleh seluruh masyarakat, dan (iii) pemanfaatan pangan atau konsumsi pangan dan gizi

Seiring berkembangnya ilmu dan pengetahuan yang makin maju maka perusahaan dituntut untuk lebih dapat menjadikan karyawannya lebih terampil dan terlatih dalam mengerjakan tugasnya. Oleh karena itu perusahaan berinisiatif untuk mengadakan progam pelatihan bagi pegawai, karena pelatihan membuat mereka lebih percaya diri sehingga menimbulkan rasa puas dalam bekerja dan lebih dihargai, serta mampu berusaha untuk meningkatkan produktivitas kerja pegawai.

Setelah program pelatihan itu dilaksanakan diharapkan adanya 
peningkatan produktivitas kerja dalam pada suatu organisasi yang dimaksudkan untuk meningkatkan hasil produktivitas kerja. Program pelatihan dianggap membawa manfaat yang cukup besar bagi organisasi seperti meningkatkan moral pegawai, meningkatkan efisiensi waktu dalam melaksanakan pekerjaannya.

Untuk mencapai tujuan yang dimaksud sudah barang tentu memerlukan keterlibatan sumber daya manusia (SDM) dalam organisasi tersebut, khususnya kemampuan administratif pegawai karena hal tersebut akan mempengaruhi efektivitas suatu organisasi. Pekerjaan yang berlainan dan ditangani oleh orang yang pendidikannya sesuai dan terampil dalam bidangnya akan mempengaruhi cara pandang, tujuan, kebutuhan, dan kemampuan yang berbeda dalam pencapaian tujuan organisasi berdasarkan visi dan misi organisasi.

Produktivitas kerja menurut Mangkunegara (2003) adalah sebagai hasil kerja secara kualitas dan kuantitas yang dapat dicapai oleh seorang karyawan/pegawai dalam melaksanakan tugas sesuai dengan tanggung jawab yang diberikan kepadanya. Pegawai di Dinas Ketahanan Pangan Kabupaten Lampung Barat sudah cukup memadai baik dari segi kuantitas maupun kualitasnya. Spesifikasi keahlian dan tingkat profesionalismenya meski sudah cukup tetapi masih perlu peningkatan, khususnya dalam memberikan dan meningkatnya keanekaragaman konsumsi pangan masyaraka untuk mewujudkan pemantapan ketahanan pangan yang tercermin dari tertanganinya desa rawan pangan, stabilnya harga dan pasokan pangan pokok.

Dengan kualitas kinerja pegawai yang semakin meningkat diharapkan adanya perubahan kerja. Kinerja pegawai yang meningkat akan menimbulkan rasa memiliki organisasi dan akan tercipta rasa kepuasan, baik pada individu maupun organisasi secara keseluruhan. Elemen yang digunakan dalam analisa ini adalah kondisi pegawai menurut jenjang pendidikan formal dan keadaan pegawai berdasarkan jenja ng pendidikan karier.

Berdasarkan faktor dan uraian di atas, maka penulis tertarik untuk menelitinya lebih lanjut dengan judul: "Pengaruh Pelatihan Kerja terhadap Produktivitas Kerja Pegawai pada Dinas Ketahanan Pangan Kabupaten Lampung Barat".

\section{KAJIAN TEORI}

\section{Pengertian Pelatihan}

Menurut Mangkunegara, A.A Anwar Prabu, Pelatihan adalah setiap usaha untuk memperbaiki performan pekerja pada suatu pekerjaan tertentu yang sedang menjadi tanggungjawabnya, atau suatu pekerjaan yang ada kaitannya dengan pekerjaannya (Mangkunegara, 2008), Supaya efektif, pelatihan biasanya harus mencakup pengalaman belajar (learning experience), aktivitas-aktivitas yang terencana (be a planned organizational activity), dan didesain sebagai jawaban atas kebutuhan-kebutuhan yang berhasil diidentifikasikan. Secara ideal, pelatihan harus didesain untuk meunjukkan tujuantujuan organisasi yang pada waktu bersamaan juga menunjukkan tujuan-tujuan dari para pekerja secara perorangan.

Istilah pelatihan sering disamakan dengan istilah pengembangan. Pengembangan (development) menunjuk pada kesempatan-kesempatan belajar (learning opportunities) yang didesain guna membantu pengembangan para pekerja. Kesempatan yang demikan tidak terbatas pada upaya perbaikan performansi pekerja pada pekerjaanya yang sekarang. Jadi pelatihan langsung berkaitan dengan performansi kerja, sedangkan pengembangan (development) tidak mesti berkaitan. Pengembangan mempunyai 
skope yang lebih luas dibandingkan dengan pelatihan.

Pelatihan sering dianggap sebagai aktivitas yang paling dapat dilihat dan paling umum dari semua aktivitas kepegawaian. Para majikan menyokong pelatihan karena melalui pelatihan para pegawai akan menjadi lebih terampil dan karenanya lebih produktif sekalipun manfaat-manpfaat tersebut dapat diperhitungkan dengan waktu yang tersisa ketika para pegawai sedang dilatih. Para pekerja menyukai pelatihan karena pelatihan membebaskan dari pekerjaan mereka (jika mereka tidak suka pada pekerjaannya) atau meningkatkan kecakapan yang bisa digunakan untuk menguasai kedudukan yang sedang mereka duduki atau yang akan mereka duduki.

Pelatihan juga sering dianggap sebagai imbalan dari organisasi dan suatu simbol status, atau suatu liburan dari kewajiban-kewajiban kerja sehari hari. Beberapa komentator yang menekankan arti simbolis dari pelatihan mengemukakan bahwa orang-orang menerima prestise dan balasan-balasan yang tidak dilihat lainnya melalui pelatihan. Oleh karena itu pelatihan juga dapat memperbaiki kepuasan kerja.

\section{Produktivitas Kerja}

Produktivitas kerja memegang peranan yang sangat penting. Karena maju mundurnya organisasi sangatlah tergantung pada naik turunnya produktivitas kerja pegawai. Seorang pegawai yang melakukan suatu jenis pekerjaan tertentu dapat dipastikan akan memperoleh hasil. Hasil adalah output akan produksi dari suatu aktivitas kerja. Produksi dan produktivitas adalah dua hal yang mempunyai hubungan yang erat dan merupakan masalah yang pokok dalam perusahaan/dinas.

Berkaitan dengan produktivitas tersebut, (Sinungan, 2013) menyatakan bahwa : "Produktivitas adalah sebagai perbandingan antara totalitas pengeluaran dengan waktu tertentu dibagi totalitas masukan selama periode tertentu, lebih lanjut dikatakan bahwa produktivitas keluaran tiap jam kerja dengan memperhatikan produktivitas kerja yang dihasilkan". Selanjutnya, Kussriyanto (2010) menyatakan "Produktivitas dapat juga diartikan sebagai suatu sikap mental yang selalu mempunyai pandangan bahwa mutu kehidupan hari ini harus lebih baik dari pada hari kemarin dan hari esok lebih baik dari hari ini".

Produktivitas ditunjukkan oleh perilakunya sebagai keluaran (output) dari suatu proses berbagai komponen kejiwaan yang melatarbelakanginya, bahwa motivasi kerja sering diwujudkan oleh produktivitas setiap individu yang terlibat didalamnya. Sebagai manusia, tenaga kerja mempunyai watak, temperamen serta karakter yang berbeda-beda, sehingga memberikan reaksi terhadap permasalahan dan lingkungan kerja mereka, hal ini merupakan masalah yang rumit dan paling untuk diperkirakan karena sebagai tenaga kerja mereka mempunyai latar belakang dengan bermacam-macam perbedaan seperti tingkat pendidikan, pengalaman, budaya, nilai dan tujuan hidup yang akan memberikan suasana kehidupan kerja yang beragam.

\section{Pengukuran Produktivitas Kerja}

Pengukuran produktivitas tenaga kerja menurut sistem pemasukan fisik perorangan/perorang atau per jam kerja orang diterima secara luas, namun dari sudut pandangan/pengawasan harian, pengukuran-pengukuran tersebut pada umumnya tidak memuaskan, dikarenakan adanya variasi dalam jumlah yang diperlukan untuk memproduksi satu unit produk yang berbeda. Oleh karena itu, digunakan metode pengukuran waktu tenaga kerja (jam, hari atau tahun). Pengeluaran diubah ke dalam unit-unit 
pekerja yang biasanya diartikan sebagai jumlah kerja yang dapat dilakukan dalam satu jam oleh pekerja yang terpercaya yang bekerja menurut pelaksanaan standar. Karena hasil maupun masukan dapat dinyatakan dalam waktu, produktivitas tenaga kerja dapat dinyatakan sebagai suatu indeks yang sangat sederhana = Hasil dalam jam-jam yang standar : Masukan dalam jam-jam waktu.

Untuk mengukur suatu produktivitas perusahaan dapatlah digunakan dua jenis ukuran jam kerja manusia, yakni jam-jam kerja yang harus dibayar dan jam-jam kerja yang dipergunakan untuk bekerja. Jam kerja yang harus dibayar meliputi semua jam-jam kerja yang harus dibayar, ditambah jam-jam yang tidak digunakan untuk bekerja namun harus dibayar, liburan, cuti, libur karena sakit, tugas luar dan sisa lainnya. Sinungan (2013) mengemukakan bahwa bagi keperluan pengukuran umum produktivitas tenaga kerja kita memiliki unit-unit yang diperlukan, yakni: kuantitas hasil dan kuantitas penggunaan masukan tenaga kerja.

\section{Faktor-faktor yang Mempengaruhi Produktivitas Kerja}

Menurut Ravianto (2012), produktivitas kerja seorang pegawai dipengaruhi oleh beberapa faktor sebagai berikut :
a. Pendidikan dan pelatihan
b. Disiplin
c. Sikap dan etika kerja
d. Motivasi kerja
e. Gizi dan kesehatan
f. Jaminan sosial
g. Lingkungan dan iklim kerja
h. Teknologi

\section{METODE PENELITIAN}

\section{Objek Penelitian}

Objek penelitian ini adalah pegawai di Dinas Ketahanan Pangan Kabupaten Lampung Barat, yang beralamat di Jln. Kapten Piere Tendean Komplek BPP Sebarus Liwa Lampung Barat. Penelitian ini di laksanakan dari bulan Mei sampai dengan Juli 2018.

\section{Metode dan Teknik Pengumpulan Data}

Dalam penelitian ini jenis data yang diperlakukan adalah :

a. Data Primer

Data primer merupakan data dasar yang akan diperoleh langsung tanpa perantara orang atau lembaga lain sebagai pihak ketiga. Data primer ini diperoleh dengan wawancara melalui responden dengan menggunakan daftar pertanyaan.

b. Data Sekunder

Data skunder merupakan data yang diperoleh melalui orang lain yang berhubungan dengan permasalahan yang dipecahkan. Data sekunder ini diperoleh melalui cara studi dokumenter yaitu mengumpulkan dan mempelajari brosurbrosur serta dokumen organisasi.

\section{Sampel dan Populasi}

Sampel penelitian adaalah sebagian dari populasi yang mewakili sifat dan karakter yang sama. Dengan mengambil sampel dimaksudkan untuk menyederhanakan jumlah subjek yang harus diteliti, tetapi hasil penelitian terhadap sampel itu akan digeneralisasikan pada populasi yang ada. Untuk menentukan banyak sampel, peneliti menggunakan pedoman dari pendapat Arikunto (2010), apabila subyeknya kurang dari 100 , lebih baik diambil semua sehingga penelitiannya merupakan penelitian populasi. Selanjutnya 
jika jumlah subyeknya besar, dapat diambil $10 \%-15 \%$ atau $20 \%-25 \%$ atau lebih. Dalam penelitian ini merupakan penelitian sampel. Adapun jumlah sampel yang diambil adalah seluruh populasi pegawai yang ada di Dinas Ketahanan Pangan Kabupaten Lampung Barat sebanyak 24 orang.

\section{Metode Analisis Data}

Untuk pengolahan data dalam bentuk tabulasi hasil jawaban responden kemudian dilakukan analisis data melalui metode analisis secara kualitatif dan analisa kuantitatif. Analisis kualitatif dilakukan dengan analisis tabel tunggal atau secara parsial yang akan menggambarkan kriteria masing-masing variabel. Analisis kuantitatif yang dilakukan berdasarkan data primer yang diperoleh dari penyebaran instrument (daftar pertanyaan) kepada sampel, dan untuk mengetahui pengaruh dari variabel bebas (independent variable) terhadap variabel terikat (dependent variable).

Persamaan Regresi Linear Sederhana menentukan persamaan regresi linear sederhana untuk $\mathrm{X}$ :

$$
Y=a+b X+e
$$

Keterangan:

$$
\begin{aligned}
& \mathrm{Y}=\text { Produktivitas kerja } \\
& \mathrm{a}=\text { Konstanta } \\
& \mathrm{b}=\text { Koefisien regresi } \mathrm{X} \\
& \mathrm{X}=\text { Pelatihan } \\
& \mathrm{e}=\text { Faktor kesalahan }
\end{aligned}
$$

Untuk mengetahui besarnya pengaruh, penghitungan koefisien korelasi tersebut kemudian dilanjutkan dengan Rumus Koefisien Determinasi atau Koefisien Penentu (KP):

$$
K P=(r)^{2} x 100 \%
$$

Untuk menguji secara hipotesis secara parsial digunakan Uji t dengan rumus :

$$
t_{\text {hitung }}=\frac{r \sqrt{N-2}}{\sqrt{1-r^{2}}}
$$

Keterangan:

$$
\begin{array}{ll}
\mathrm{t}_{\text {hitung }} & =\text { Nilai } \mathrm{t} \\
\mathrm{r} & = \\
\mathrm{N} & \text { Koefisien Korelasi } \\
= & \text { Jumlah responden } \\
& \quad(\text { Sugiyono, 2008). }
\end{array}
$$

Kriteria untuk Uji $\mathrm{t}$ adalah sebagai berikut :

a) Jika $t_{\text {hitung }}>t_{\text {tabel }}$ maka Ha diterima dan Ho ditolak.

b) Jika $\mathrm{t}_{\text {hitung }} \leq \mathrm{t}$ tabel maka Ha ditolak dan Ho diterima.

Taraf signifikan dalam penelitian ini digunakan $\alpha=0,05$ atau 5\%. Yang dimaksud dengan Hipotesis nol (Ho) dan Hipotesis alternatif $(\mathrm{Ha})$ adalah :

Ho $=r \leq 0=$ Berarti tidak ada pengaruh pelatihan terhadap produktivitas kerja $\mathrm{Ha}=\mathrm{r}>0=$ Berarti ada pengaruh pelatihan terhadap produktivitas kerja.

\section{HASIL DAN PEMBAHASAN}

Data penelitian yang telah dikumpulkan kemudian diolah untuk menguji kualitas data berupa uji validitas dan reliabilitas menunjukkan bahwa koefisien korelasi pearson moment untuk setiap item butir pertanyaan dengan skor total variabel Pelatihan (X), dan Produktivitas kerja (Y) signifikan pada tingkat signifikan $\alpha 0,05$. Dengan demikian dapat diinterprestasikan bahwa setiap item indikator instrumen masing-masing variabel tersebut valid. Artinya item-item yang tersaji dalam kuesioner benar-benar mampu mengungkapkan dengan pasti apa yang akan diteliti. Secara ringkas uji validitas 
variabel dapat dilihat pada Tabel 1 dan Tabel 2.

Tabel 1. Hasil Uji Validitas Instrumen Variabel Pelatihan

\begin{tabular}{lccc}
\hline Indikator & r hitung & r tabel & Keterangan \\
\hline X1 & 0.818 & 0.404 & Valid \\
X2 & 0.896 & 0.404 & Valid \\
X3 & 0.668 & 0.404 & Valid \\
X4 & 0.898 & 0.404 & Valid \\
X5 & 0.816 & 0.404 & Valid \\
X6 & 0.818 & 0.404 & Valid \\
X7 & 0.801 & 0.404 & Valid \\
X8 & 0.811 & 0.404 & Valid \\
X9 & 0.812 & 0.404 & Valid \\
X10 & 0.814 & 0.404 & Valid \\
\hline
\end{tabular}

Nilai $r$ hitung lingkungan kerja lebih besar dari $r$ tabel (0.514), sehingga seluruh indikator dinyatakan valid.

Tabel 2. Hasil Uji Validitas Instrumen Variabel Produktifitas kerja

\begin{tabular}{lccc}
\hline Indikator & r hitung & r tabel & Keterangan \\
\hline Y1 & 0.8838 & 0.404 & Valid \\
Y2 & 0.921 & 0.404 & Valid \\
Y3 & 0.876 & 0.404 & Valid \\
Y4 & 0.778 & 0.404 & Valid \\
Y5 & 0.835 & 0.404 & Valid \\
Y6 & 0.843 & 0.404 & Valid \\
Y7 & 0.680 & 0.404 & Valid \\
Y8 & 0.935 & 0.404 & Valid \\
Y9 & 0.816 & 0.404 & Valid \\
Y10 & 0.718 & 0.404 & Valid \\
\hline
\end{tabular}

Tabel 2. Menunjukkan hasil perhitungan seluruh indikator untuk variabel produktifitas kerja adalah lebih besar dari $r$ tabel, sehingga seluruh indikator dinyatakan valid.

\section{Uji Reliabilitas Data}

Nilai reliabilitas konsistensi internal menunjukkan bahwa koefisien Alpha Cronbach dinyatakan reliabel karena lebih besar dari 0,60. Dengan demikian item pengukuran pada masing-masing indikator dalam variabel-variabel penelitian dinyatakan reliabel dan selanjutnya dapat digunakan dalam penelitan.

\section{Analisis Kuantitatif}

Berdasarkan pengujian yang diperoleh persamaan regresi linier sederhana adalah Y $=13,859+0,423(\mathrm{X})$. Nilai konstanta yang diperoleh sebesar 13,859, hal ini berarti bahwa jika variabel independen (pelatihan) adalah bernilai nol, maka besarnyaproduktifitas kerja yang terjadi adalah 13,859. Nilai koefisien regresi variabel pelatihan $(\mathrm{X})$ sebesar 0,423 , hal ini menunjukkan bahwa setiap kenaikan satu satuan pelatihan akan mengakibatkan produktifitas kerja sebesar 0,423.

Koefisien determinan $\left(\mathrm{R}^{2}\right)$ digunakan untuk mengetahui kontribusi variabel bebas dalam menjelaskan variabel terikat. Semakin besar nilai koefisien determinasimaka menunjukkan semakin besar pula pengaruh variabel terikat terhadap variabel bebas. Hasil pengujian menunjukkan bahwa nilai $R$ square sebesar 0.495 Nilai $R$ square ini menunjukkan bahwa besarnya kontribusi variabel independen terhadap variabel dependen adalah sebesar $49,5 \%$, sedangkan sisanya sebesar 50,5\% ditentukan oleh variabel lain yang tidak teridentifikasi dalam penelitian ini.

Pengujian statistik dilakukan untuk menjawab model kelayakan hipotesis penelitian. Pengujian dilakukan dengan menggunakan uji $\mathrm{t}$ pada tingkat kepercayaan $95 \%$ atau $\alpha$ sebesar 0,05 , apabila $t_{\text {hitung }}>t_{\text {tabel. }}$. Maka model dinyatakan layak digunakan dalam penelitian ini dan sebaliknya apabila $t_{\text {hitung }}<t_{\text {tabel, }}$ maka model dikatakan tidak layak, atau dengan signifikan (Sig) < 0.05 maka model dinyatakan layak digunakan dalam penelitian ini dan sebaliknya apabila 
signifikan $($ Sig) $>0.05$ maka model dinyatakan tidak layak digunakan. Hasil pengujian dapat menjawab hipotesis yang menyatakan "pelatihan berpengaruh terhadap produktifitas kerja". Pengujian dilakukan dengan menggunakan uji t yang menunjukkan bahwa pelatihan berpengaruh terhadap produktifitas kerja.

Pengujian dilakukan dengan menggunakan uji t pada tingkat keyakinan signifikansi $\alpha 0,05$, diketahui bahwa tingkat signifikansi sebesar $0,00<0,05$ dengan nilai $t_{\text {hitung }}>t_{\text {tabel }}$ yaitu 4,640>2,068, dengan demikian hipotesis diterima yang berarti pelatihan berpengaruh terhadap produktifitas kerja pada Dinas Ketahanan Pangan Kabupaten Lampung Barat.

\section{KESIMPULAN DAN SARAN}

\section{Kesimpulan}

Berdasarkan hasil penelitian dapat disimpulkan hasil pengujian menunjukkan bahwa nilai $R$ square sebesar 0,495 Nilai $R$ square ini menunjukkan bahwa besarnya kontribusi variabel independen terhadap variabel dependen adalah sebesar 49,5\%, sedangkan sisanya sebesar 50,5 \% ditentukan oleh variabel lain yang tidak teridentifikasi dalam penelitian ini. Pengujian dilakukan dengan menggunakan uji t yang menunjukkan bahwa pelatihan berpengaruh terhadap produktifitas kerja. Pengujian dilakukan dengan menggunakan uji t pada tingkat keyakinan signifikansi $\alpha$ 0,05. Dari hasil dapat diketahui bahwa tingkat signifikansi sebesar $0,00<0,05$ dengan nilai thitung $>t_{\text {tabel }}$ yaitu 4,640> 2,068, dengan demikian hipotesis diterima yang berarti pelatihan berpengaruh terhadap produktifitas kerja pada Dinas Ketahanan Pangan Kabupaten Lampung Barat.

\section{Saran}

Adapun saran yang diajukan peneliti adalah sebagai berikut:

1. Dinas Ketahanan Pangan Kabupaten Lampung Barat hendaknya sering melakukan pelatihan yang bermanfaat bagi pegawainya dengan demikian produktivitas pegawai semakin meningkat.

2. Dinas Ketahanan Pangan Kabupaten Lampung Barat hendaknya memberikan tambahan pelatihan yang sesuai kepada staf/pegawainya sehingga dapat bekerja dengan baik sesuai yang diharapkan

3. Pimpinan Dinas Ketahanan Pangan Kabupaten Lampung Barat hendaknya memberikan reward kepada pegawainya sesuai dengan kemampuan dan kualitas yang dimiliki sesuai dengan kinerjanya.

4. Dilakukan penelitian lagi untuk meneliti yang $50,5 \%$.

\section{DAFTAR PUSTAKA}

Algifari. 2013. Statistik Penelitian. Jakarta: Presshindo.

Anoraga, Panji. 2013. Lingkungan Fisik Kerja. Jakarta: Rajawali Perdana.

Arikunto, Suharsimi. 2010. Metode Penelitian. Jakarta: BP FE UI.

Bodnar, George H., dan William S. Hopwood. 2010. Pembinaan untuk Meningkatkan Kinerja Karyawan. Penerjemah Ramlan. Jakarta: PPM.

Eka Pertiwi. 2011. Pengaruh Peningkatan Pendidikan dan latihan (Diklat) Terhadap Produktivitas Kerja Pegawai Pada Dinas Perhubungan Kabupaten Lampung Utara.

Ferdinand. 2008. Metode Penelitian Bisinis. Bandung: ANDI offset. 
Kussriyanto. 2010. Administrasi Kepegawaian suatu Pengembangan. Jakarta: Rajawali.

Mangkunegara, Anwar P. 2008. Manajemen Sumber Daya Manusia Perusahaan. Bandung: PT. Remaja Rosdakarya.

Nitisemito, Alex S. 2009. Manajemen Sumber Daya Manusia. Jakarta: Penerbit Indonesia.

Ravianto, John. 2012. Produktivitas dan Pengukuran. Jakarta: Penerbit Lembaga Sarana Informasi Usaha dan Produktivitas.

Safrudin, 2014. Analisis Pelaksanaan Pendidikan dan Pelatihan Dalam Upaya Peningkatan Kinerja Pegawai Negeri Sipil Di Dinas Kelautan Dan Perikanan Pemerintah Kabupaten Lampung Selatan

Sedarmayanti. 2009. Sumber Daya Manusia dan Produktivitas Kerja. Bandung: Mandar Maju.

Siagian, Sondang P. 2012. Peranan Staf dan Manajemen. Jakarta: CV.Gunung Agung.

Sinungan, M. 2013. Produktivitas Apa dan Bagaimana. Jakarta: Bumi Aksara.

Suharsimi, Arikunto. 2010. Prosedur Penelitian, Edisi Kelima. Penerbit. Jakarta: Bineka Cipta.

Sugiyarso, G., dan F. Winarni. 2008. Manajemen Sumber Daya Manusia. Jilid 2. Jakarta: Salemba Empat.

Sugiyono. 2012. Metode Penelitian Kuantitatif dan Kualitatif dan $R \& D$. Bandung: CV. Alpha Beta.
Sundari. 2016. Pengaruh Pelatihan Terhadap Produktivitas Kerja Pada PT.Telkom Devisi Lampung

Sutrisno, Edy. 2010. Manajemen Personalia dan Sumber Daya Manusia, Edisi 2. Jakarta: BPFE.UI.

Tarwaka, dkk. 2014. Produktivitas dan Manusia Indonesia. Jakarta: Ghalia Indonesia. 